\title{
The Economic Impact of Individual Fires on the Whole Forest
}

\author{
C. E. Van Wagner
}

\author{
Canadian Forestry Service \\ Petawawa Forest Experiment Station \\ Chalk River, Ontario
}

\begin{abstract}
A method is presented whereby the economic impact of a forest fire can be calculated, not just on the burned stand alone, but on the entire area under management. The main question is whether, when the burned area would have been ready for harvesting, another area will be substituted in its place. If so, then the economic impact is diffused throughout all stands younger or less desirable than the burned one, and the present value of the burned stand only may not be a fair measure of loss. The true loss would be, instead, the change in present value of the whole forest as a result of the fire. Some examples are given, and the effects of varying the rates of interest and forest growth are illustrated.
\end{abstract}

\section{Résumé}

On présente une méthode qui permet de calculer les répercus. sions économiques d'un incendie de forêt, non seulement sous le rapport du peuplement brûlé, mais pour toute la zone aménagée. La principale question est de savoir si on doit remplacer par une autre une surface incendiée au moment ou elle aurait été prête pour la récolte. Si c'est le cas, il faut étendre les répercussions économiques à l'ensemble des peuplements plus jeunes ou plus médiocres que le peuplement incendié. Alors, la valeur présente du peuplement incendié peut ne pas représenter une mesure exacte de la perte. La valeur véritable de la perte serait plutôt le changement de la valeur présente de la forêt tout entière en raison de l'incendie. Un certain nombre d'exemples sont donnés ainsi qu'une illustration des effets causés par la fluctuation des taux d'intérêt et par la croissance forestière.

\section{Introduction}

The problem of estimating the loss due to a forest fire has always been a difficult one. The main question is that one seldom knows just what would have been done with the burned area if it had not burned. Even if perchance a definite plan to cut or otherwise use the burned area did exist before the fire, alternate areas were probably available. If so, then the exact loss if not easy to specify. One way out of this difficulty is to consider the economic impact of the forest fire, not just on the burned area itself, but rather on the whole area under management. A method by which this might be accomplished is presented here, using the twin concepts of age-class distribution and present value.

A principle common to much of the literature on the economic effects of forest fires is that the present value of a burned forest stand, discounted from its expected value at maturity, is a fair estimate of loss. In Canada, for example, Mactavish (1966) and McLean (1970) based their estimates of loss due to fire in immature stands on this idea; similar American examples are Lindenmuth et al. (1951) and Crosby (1977). Davis (1954) in turn bases his discussion of fire loss (Chap. 21) on the work of Lindenmuth et al. This principle is based on an important assumption, very seldom stated, but described by McLean (1970, p. 8 ) that "stumpage sales in the forest district where the fire occurred will be reduced at the expected date of stand maturity by the (value of the firekilled timber)." In other words, in the year during which the burned stand would have matured, a harvest equal to the mature value of the burned timber will be completely forgone, and no substitute will be sought. In reality, however, more often than not, when the burned stand would have matured the next most desirable stand is cut in its place. All other stands are then promoted accordingly and the burned area is placed at the end of the list. The approach to fire loss appraisal presented here incorporates this concept of substitution into a calculation of the change in the present value of the whole forest as a result of fire.

This key question of substitution has been referred to by a number of authors. Davis (1954, p. 44) hinted at this principle, saying "In the case of a forest property managed on a sustained-yield basis, damage to a part of it is most validly measured by the effect on the yield of the property as a whole", but did not pursue the idea quantitatively. Simard (1976) dwelt at length on the importance of substitution in assessing fire loss, and also mentioned the use of present value calculation when assessing loss. He said, furthermore, that "future benefits resulting from the fire, such as a vegetative mosaic or a new stand of vigorous timber to replace an old decadent stand should be included." If substitution is assumed, then the impact of the fire is diffused among all other existing stands of equal age or younger, and the economic effect is most logically calculated as the difference before and after the fire in the present value of the whole forest. Furthermore, a net benefit, if it were possible, should show up in this procedure as readily as a net loss.

\section{Method}

An estimate of the present value of a whole forest can only be based, in the words of Davis (1954, p. 346) "on the assumption of continued management according to a specific plan ..." The plan adopted for present purposes is that the whole forest shall be cut in such a manner as to render it perfectly regulated at the end of one rotation. In other words, consider the forest to be divided into the appropriate number of units, these to be cut one every year in order of decreasing age regardless of the initial age-class distribution. After one rotation, the forest would then consist of equal-sized areas of each age class up to rotation age. This plan is chosen because it results in a forest of maximum present value for a given rotation, and also because, whether the forest is truly scheduled for cutting in this manner or not, such an optimum hypothetical plan forms a consistent basis for loss appraisal.

To allow the problem to be stated and solved as easily as possible, some assumptions are desirable:

1) The forest is composed of distinct even-aged stands.

2) Fire kills the forest at any age.

3) Fire is followed by immediate regeneration.

4) Value of salvage and cost of regeneration can be considered separately if necessary and are outside the present argument.

The equation for the present value of one even-aged stand that will be harvested at maturity is

$\mathrm{v}_{\mathrm{o}}=\mathrm{v}_{\mathrm{r}} /(1+\mathrm{i})^{\mathrm{n}}$

where vi $=$ is interest rate,

$\mathrm{r}=$ is age at maturity (rotation age),

$\mathrm{n}=$ is number of years until harvest,

$\mathrm{v}_{\mathrm{r}}=$ is value at maturity,

$\mathrm{v}_{\mathrm{o}}=$ is present value. 
If the whole forest is perfectly regulated, consisting of one stand at each age up to rotation age, then the present value of the whole standing forest $\left(V_{0}\right)$ is the "present value of an annuity" of $v_{r}$ for $r$ year.

$$
V_{o}=v_{r} \frac{(1+i)^{r}-1}{i(1+i)^{r}}
$$

If, however, the whole forest is not perfectly regulated, assume, as argued above, that an equal area, $1 / \mathrm{r}$ of the whole, will be cut each year, beginning with the oldest. The stands can be arrayed in order of decreasing age, the whole array divided into $r$ equal-sized units, and their individual present values computed and summed. That is,

$$
V_{0}=\sum_{n=1}^{n} \sum_{r}^{r} v_{j} /(1+i)^{n}
$$

where $v_{j}$ is value of unit $j$ at time of harvesting, $j$ being a permanent label. Since some stands will be cut at ages other than the ideal rotation age, a function or curve describing the relation between value and age will therefore be required, carried far enough past maturity to accommodate the oldest stand at its prospective harvest age. This latter age is simply $x+n$, where $x$ is present age and $n$ is, as before, the number of years until harvest; $n$ can also be considered the temporary rank of the unit beginning $n=1$ for the oldest. Equation 3 assumes tabulation at the end of the fire season, the annual cut having been taken earlier in the year.

\section{Examples}

At this point some hypothetical examples would be useful, both to illustrate the calculation of loss on the whole-forest basis and to compare it with the burned-area-only basis. In the choice of conditions for these examples, it is impossible to avoid saying something about interest rates. There are two problems, the first being that of inflation, which greatly complicates any calculations involving the long-term compounding of interest. For present purposes the value of money will be assumed constant, on grounds that the effect of inflation should not change the principle being illustrated, and could be introduced if desired in any practical application. The discount rates used for calculating present values in the following examples therefore supposedly represent conservative real rates of return for business purposes.

The second problem with respect to interest is the relationship between forest value and age; in particular, the rate of value increase as the forest approaches maturity has a great bearing on the results. For example, in Canada at least, many forests increase in value at rates less than any reasonable alternate discount rate. In designing examples, the best that can be done is to choose rates of value increase and discount that illustrate certain important points in the comparison of the two methods.

First is a demonstration of the tabulation and calculation of a simple case of the whole-forest approach to fire impact appraisal.

Imagine a forest 100 area units in size with a chosen rotation of $100 \mathrm{yr}$, perfectly regulated so that there is one area unit for each single-year age class. Some further arbitrary assumptions are:

1) Each unit has a relative value of 1 at maturity.

2) Value equals age/ 100 when cut at other ages; i.e., rate of value increase is $1 \%$.

3) Discount rate is $6 \%$

The present value $V_{0}$ of this forest before fire is readily calculated by Equation 2; it is 16.62 . After fire, the forest is no longer perfectly regulated and Equation 3 must be used.
Table 1 is an abbreviated version of the tabulation required to compute the impact of a fire in Unit 5 . The post-fire present value is 16.49 ; the difference of 0.13 represents the loss due to the fire.

Next are three examples (A, B,and C) comparing the results of the two methods of fire impact appraisal. They show also the effects of varying the rates of discount and value increase in relation to one another. They are based on the same perfectly regulated forest assumed above with conditions as shown in the following tabulation.

\begin{tabular}{l|c|c|c}
\multicolumn{1}{c}{ Item } & $\begin{array}{c}\text { Example } \\
\text { A }\end{array}$ & $\begin{array}{c}\text { Example } \\
\text { B }\end{array}$ & $\begin{array}{c}\text { Example } \\
\text { C }\end{array}$ \\
\hline $\begin{array}{l}\text { Rotation length and } \\
\text { number of units }\end{array}$ & 100 & 100 & 100 \\
$\begin{array}{c}\text { Relative value per unit at } \\
\text { maturity }\end{array}$ & 1 & 1 & 1 \\
$\begin{array}{c}\text { Average rate of value } \\
\text { increase }\end{array}$ & $1 \% / \mathrm{yr}$ & $1 \% / \mathrm{yr}$ & $3 \% / \mathrm{yr}$ \\
$\begin{array}{l}\text { Alternate discount rate } \\
\text { Effects of fires in unit } \\
\text { numbers }\end{array}$ & $6 \%$ & $3 \%$ & $3 \%$ \\
& $1,5,50$, & $1,5,50$, & $1,5,50$, \\
Results in & 95,100 & 95,100 & 95,100 \\
& Table 2 & Table 3 & Table 4 \\
\hline
\end{tabular}

The significant features of Examples $A$ and $B$ are that, first, the discount rate is greater than the rate of forest value increase, and, second, that this difference is much greater in $A$ than in $B$. The significance of Example $C$ is that the rates of discount and value increase are equal. The results of Examples A, B. and C are in Tables 2, 3, and 4. In each table, the economic impacts of the individual fires are listed by the whole-forest method (W) and by the burned-area-only method $(B)$. The right-hand column of each table lists the ratios of $W$ to $B$.

\section{Discussion}

With any appreciable rotation length and discount rate, it is apparent that evaluating the change in present value of the whole forest gives a lower estimate of fire loss than the simple present value of the burned forest. Examples $A$ and $B$ (Tables 2 and 3 ) best illustrate this point. However, if the rate of value increase of the forest approaches the discount rate, then the two measures of fire loss, for mature stands at least, may give about the same value. This case is best illustrated by Example $C$ in Table 4 . Probably most of the Canadian forest would fit Examples $A$ and $B$ better than Example C.

Just what constitutes the "whole forest" is a matter of judgement. It could be the working area of one license, or a large region, or even an entire provincial forest. Also relevant is the level of authority estimating the loss. What might be a difficult substitution in a small working area could perhaps be accomplished in an adjacent one.

The age of the burned stand has an obvious effect on the fire's economic impact, due of course to the discount effect. However, it is also apparent that the whole-forest fire loss estimate is proportionately less in comparison with the burned-area-only estimate as age decreases. This is apparent in all three Examples A, B, and C. At very young age, absolute loss is small but the proportional difference between the methods is very great.

In any comparison of the whole-forest and burned-areaonly approaches to fire loss, the question of subsitution is crucial. As long as a substitute can be found for the burned unit when it would have been harvested, the present value of the burned area only will generally overestimate the economic impact, sometimes by a wide margin. The difference between the two approaches will depend on the rotation length, discount rate chosen, rate of forest value in- 
Table 1. Form of tabulation leading to present value of a regulated forest (see text) after a fire in Unit 5, as for processing by Equation 3. (Same fire as in row 2 of Table 2).

\begin{tabular}{|c|c|c|c|c|c|}
\hline$\underset{\mathbf{j}}{\underset{\text { Unit }}{\text { Uumber, }}}$ & $\begin{array}{c}\text { Age after } \\
\text { annual } \\
\text { harvest } \\
\text { or fire } \\
\text { (if any) } \\
\text { x }\end{array}$ & $\begin{array}{c}\text { Age } \\
\text { rank, } \\
\text { n }\end{array}$ & $\begin{array}{l}\text { Harvest } \\
\text { age, } \\
\mathbf{x}+\mathbf{n}\end{array}$ & $\begin{array}{c}\text { Harvest } \\
\text { value } \\
\left(\begin{array}{c}\mathbf{x}+\mathbf{n}) / \\
100\end{array}\right.\end{array}$ & $\begin{array}{c}\text { Present } \\
\text { value, } \\
\mathbf{v}_{\mathrm{o}}\end{array}$ \\
\hline $\begin{array}{l}1 \\
2 \\
3 \\
4 \\
6\end{array}$ & $\begin{array}{l}99 \\
98 \\
97 \\
96 \\
94\end{array}$ & $\begin{array}{l}1 \\
2 \\
3 \\
4 \\
5\end{array}$ & $\begin{array}{r}100 \\
100 \\
100 \\
100 \\
99\end{array}$ & $\begin{array}{l}1 \\
1 \\
1 \\
1 \\
0.99\end{array}$ & $\begin{array}{l}.94340 \\
.89000 \\
.83962 \\
.79209 \\
.73979\end{array}$ \\
\hline . & . & . & . & . & . \\
\hline $\begin{array}{r}99 \\
100 \\
5\end{array}$ & $\begin{array}{l}\mathrm{i} \\
0 \\
0\end{array}$ & $\begin{array}{r}98 \\
99 \\
100\end{array}$ & $\begin{array}{r}99 \\
99 \\
100\end{array}$ & $\begin{array}{l}0.99 \\
0.99 \\
1\end{array}$ & $\begin{array}{l}.00328 \\
.00309 \\
.00925\end{array}$ \\
\hline & & \multicolumn{3}{|c|}{$\mathrm{V}_{\mathrm{o}}=\Sigma \mathrm{v}_{0}=$} & 16.48606 \\
\hline
\end{tabular}

crease, and age of the burned area.

If fire could ever produce a positive economic impact, one might expect it to show up in a calculation of change in whole forest value. However, the very low present value of zero-age forest for any practical rotation and discount rate renders this effect insignificant in a simple before-and-after value calculation. When a decadent stand of near-zero value burns, the age-class distribution of the forest may well have been improved and natural regeneration accomplished free of charge, but additional calculation would be needed to demonstrate this benefit. It would be, in fact, very difficult to portray all the ecological implications of forest fire in terms of economics.

Many complicating factors and aspects of forest valuation have been bypassed in this paper, which was intended to discuss a principle in its simplest form. More complex cases of age-class distribution at various rotations, interest rates, amd value-age relationships could be readily processed by computer. The examples given here are in terms of timber value only, but the principle, if valid, could be extended to include any forest value dependent on age, as well as disturbances other than fire.

Table 2. Comparison of "whole-forest" and "burned-area-only" fire-loss estimates for the Example A forest. Fire in five units of various ages, each calculated separately.

\begin{tabular}{|c|c|c|c|c|c|c|}
\hline \multirow{2}{*}{$\begin{array}{c}\text { Fire in } \\
\text { unit } \\
\text { number }\end{array}$} & \multirow{2}{*}{$\begin{array}{c}\text { Age } \\
\text { before } \\
\text { fire }\end{array}$} & \multicolumn{2}{|c|}{$\begin{array}{l}\text { Present value of } \\
\text { whole forest }\end{array}$} & \multicolumn{2}{|c|}{$\begin{array}{l}\text { Fire loss as decrease } \\
\text { in present value of }\end{array}$} & \multirow[b]{2}{*}{$\begin{array}{l}\text { Ratio } \\
\text { W/B }\end{array}$} \\
\hline & & Before fire & After fire & $\begin{array}{l}\text { Whole forest } \\
\text { (W) }\end{array}$ & $\begin{array}{l}\text { Burned area } \\
\text { only (B) }\end{array}$ & \\
\hline $\begin{array}{r}1 \\
5 \\
50 \\
95 \\
100\end{array}$ & $\begin{array}{r}99 \\
95 \\
50 \\
5 \\
0\end{array}$ & $\begin{array}{c}16,61755 \\
, " \\
" \\
"\end{array}$ & $\begin{array}{l}16.45140 \\
16.48606 \\
16.60848 \\
16.61737 \\
16.61752\end{array}$ & $\begin{array}{l}0.16615 \\
0.13149 \\
0.00907 \\
0.00018 \\
0.00003\end{array}$ & $\begin{array}{l}0.94340 \\
0.74726 \\
0.05429 \\
0.00394 \\
0.00295\end{array}$ & $\begin{array}{l}0.176 \\
0.176 \\
0.167 \\
0.046 \\
0.010\end{array}$ \\
\hline
\end{tabular}

Table 3. Gomparison of "whole-forest" and "burned-area-only" fire-loss estimates for the Example B forest. Fire in five units of various ages, each calculated separately.

\begin{tabular}{|c|c|c|c|c|c|c|}
\hline \multirow{2}{*}{$\begin{array}{l}\text { Fire in } \\
\text { unit } \\
\text { number }\end{array}$} & \multirow{2}{*}{$\begin{array}{c}\text { Age } \\
\text { before } \\
\text { fire }\end{array}$} & \multicolumn{2}{|c|}{$\begin{array}{c}\text { Present value of } \\
\text { whole forest }\end{array}$} & \multicolumn{2}{|c|}{$\begin{array}{l}\text { Fire loss as decrease } \\
\text { in present value of }\end{array}$} & \multirow[b]{2}{*}{$\begin{array}{l}\text { Ratio } \\
\text { W/B }\end{array}$} \\
\hline & & Before fire & After fire & $\begin{array}{l}\text { Whole forest } \\
\text { (W) }\end{array}$ & $\begin{array}{l}\text { Burned area } \\
\text { only (B) }\end{array}$ & \\
\hline $\begin{array}{r}1 \\
5 \\
50 \\
95 \\
100\end{array}$ & $\begin{array}{r}99 \\
95 \\
50 \\
5 \\
0\end{array}$ & $\begin{array}{c}31.59893 \\
", \\
" \\
"\end{array}$ & $\begin{array}{l}31.28348 \\
31.32065 \\
31.53849 \\
31.59610 \\
31.59893\end{array}$ & $\begin{array}{l}0.31545 \\
0.27828 \\
0.06044 \\
0.00283 \\
0.00000\end{array}$ & $\begin{array}{l}0.97087 \\
0.86261 \\
0.22811 \\
0.06032 \\
0.05203\end{array}$ & $\begin{array}{r}0.325 \\
0.323 \\
0.265 \\
0.047 \\
0\end{array}$ \\
\hline
\end{tabular}

Table 4. Comparison of "whole-forest" and "burned-area-only" fire-loss estimates for the Example C forest. Fire in five units of various ages, each calculated separately.

\begin{tabular}{|c|c|c|c|c|c|c|}
\hline \multirow{2}{*}{$\begin{array}{l}\text { Fire in } \\
\text { unit } \\
\text { number }\end{array}$} & \multirow{2}{*}{$\begin{array}{c}\text { Age } \\
\text { before } \\
\text { fire }\end{array}$} & \multicolumn{2}{|c|}{$\begin{array}{l}\text { Present value of } \\
\text { whole forest }\end{array}$} & \multicolumn{2}{|c|}{$\begin{array}{l}\text { Fire loss as decrease } \\
\text { in present value of }\end{array}$} & \multirow[b]{2}{*}{$\begin{array}{l}\text { Ratio } \\
\text { W/B }\end{array}$} \\
\hline & & Before fire & After fire & $\begin{array}{l}\text { Whole forest } \\
\text { (W) }\end{array}$ & $\begin{array}{l}\text { Burned area } \\
\text { only (B) }\end{array}$ & \\
\hline $\begin{array}{r}1 \\
5 \\
50 \\
95 \\
100\end{array}$ & $\begin{array}{r}99 \\
95 \\
50 \\
5 \\
0\end{array}$ & $\begin{array}{c}31,59893 \\
, " \\
, \\
"\end{array}$ & $\begin{array}{l}30.65257 \\
30.76409 \\
31.41762 \\
31.59044 \\
31.59893\end{array}$ & $\begin{array}{l}0.94636 \\
0.83484 \\
0.18131 \\
0.00849 \\
0.00000\end{array}$ & $\begin{array}{l}0.97087 \\
0.86261 \\
0.22811 \\
0.06032 \\
0.05203\end{array}$ & $\begin{array}{r}0.975 \\
0.968 \\
0.795 \\
0.141 \\
0\end{array}$ \\
\hline
\end{tabular}




\section{Acknowledgement}

Thanks are due to T. L. Pickett, Computer Programmer at the Petawawa Forest Experiment Station, who devised the "fire loss game" for processing changes in the present value of a whole forest.

\section{References}

Crosby, J. S. 1977. A guide to the appraisal of wildfire damages, benefits, and resource values protected. U.S. Forest Serv. Res. Pap. NC-142.
Davis, K. P. 1954. American forest management. McGraw-Hill. $482 \mathrm{p}$.

Lindenmuth, A. W., J. J. Keetch, and R. M. Nelson. 1951. Forest fire damage appraisal procedures and tables for the northeast. U.S. Forest Serv. South. Forest Exp. Sta. Pap. 11.

Mactavish, J. S. 1966. Appraising fire damage to mature forest stands. Can. Dep. Forest. Rural Develop., Forest. Br. Dep. Pub. 1162.

McLean, D. L. 1970. Appraisal of damage to immature timber. Can. Forest. Serv., Forest Fire Res. Inst. Inform. Rep. FFX-22.

Simard, A. J. 1976. Wildland fire management: the economics of policy alternatives. Can. Forest. Serv. Forest. Tech. Rep. 15.

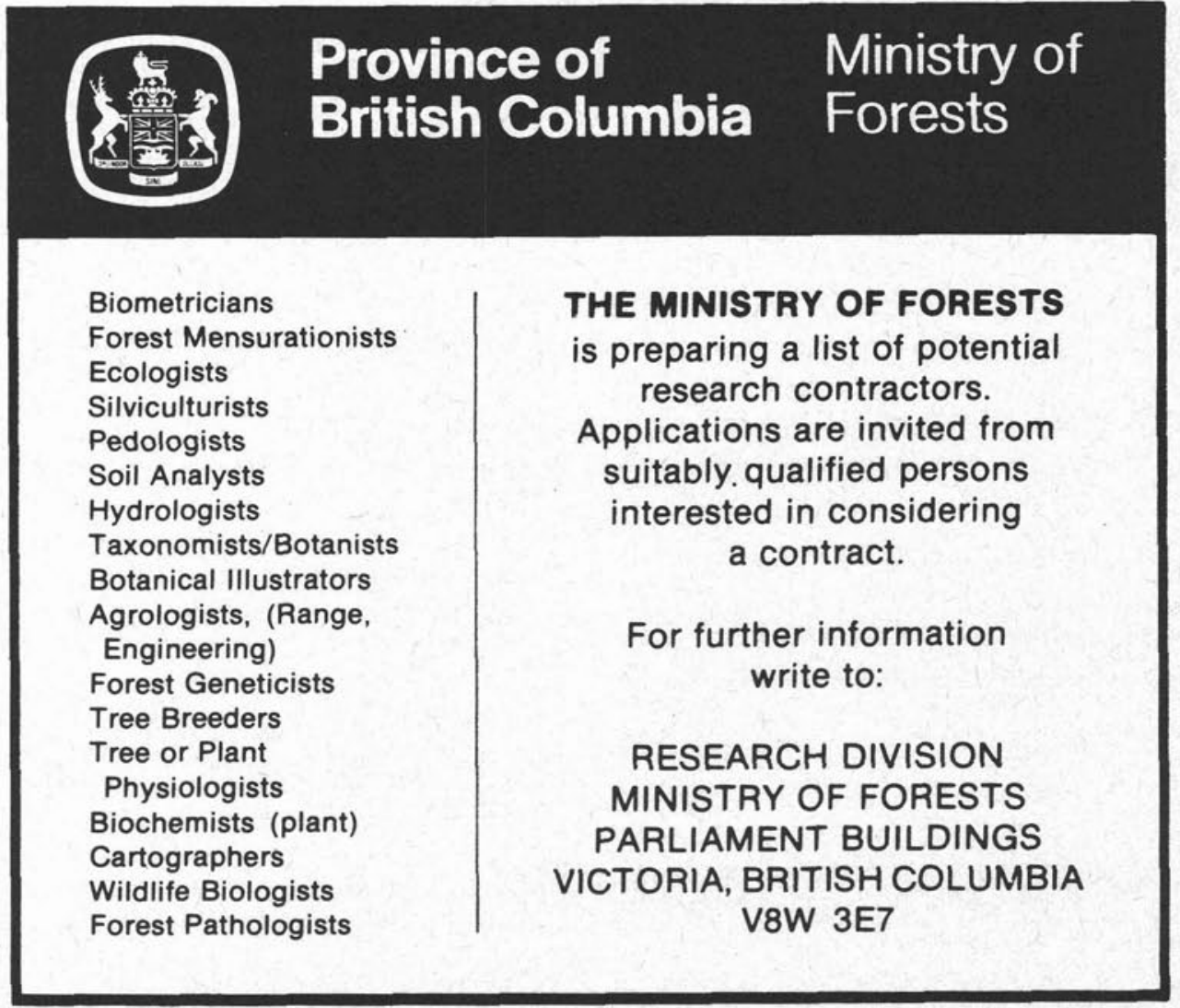

